\title{
A New View of Microcrystalline Silicon: The Role of Plasma Processing in Achieving a Dense and Stable Absorber Material for Photovoltaic Applications
}

\author{
Grégory Bugnon,* Gaetano Parascandolo, Thomas Söderström, Peter Cuony, \\ Matthieu Despeisse, Simon Hänni, Jakub Holovský, Fanny Meillaud, and Christophe Ballif
}

To further lower production costs and increase conversion efficiency of thin-film silicon solar modules, challenges are the deposition of high-quality microcrystalline silicon ( $\mu \mathrm{C}-\mathrm{Si}: \mathrm{H})$ at an increased rate and on textured substrates that guarantee efficient light trapping. A qualitative model that explains how plasma processes act on the properties of $\mu \mathrm{c}-\mathrm{Si}: \mathrm{H}$ and on the related solar cell performance is presented, evidencing the growth of two different material phases. The first phase, which gives signature for bulk defect density, can be obtained at high quality over a wide range of plasma process parameters and dominates cell performance on flat substrates. The second phase, which consists of nanoporous 2D regions, typically appears when the material is grown on substrates with inappropriate roughness, and alters or even dominates the electrical performance of the device. The formation of this second material phase is shown to be highly sensitive to deposition conditions and substrate geometry, especially at high deposition rates. This porous material phase is more prone to the incorporation of contaminants present in the plasma during film deposition and is reported to lead to solar cells with instabilities with respect to humidity exposure and post-deposition oxidation. It is demonstrated how defective zones influence can be mitigated by the choice of suitable plasma processes and silicon sub-oxide doped layers, for reaching high efficiency stable thin film silicon solar cells.

photovoltaic electricity in the coming years. ${ }^{[1,2]}$ However, this requires overcoming two main challenges, which are i) to significantly improve efficiency and ii) to further reduce production costs. The use of microcrystalline silicon ( $\mu \mathrm{c}-\mathrm{Si}: \mathrm{H})$ as an absorber layer in tandem or triple junctions has proven to be the key to achieving higher conversion efficiencies. ${ }^{[3-8]}$ As of yet, the micromorph tandem cell configuration represents one of the most effective approaches for the fabrication of highly efficient thin-film solar cell devices, aiming for $14 \%$ stable efficiency in the short term. ${ }^{[9,10]}$ Based on the monolithic interconnection of an amorphous silicon top cell (a-Si:H) and a $\mu \mathrm{c}-\mathrm{Si}: \mathrm{H}$ bottom cell, with a total thickness that can be reduced to $1 \mu \mathrm{m}$ or less, the micromorph concept's main advantages are the large availability and non-toxicity of the raw materials used, providing excellent scale-up capability to terawatt levels. ${ }^{[11]}$ Another advantage lies in its compatibility with mass-production and low-temperature processes for both superstrate and low-cost flexible substrate configurations. Based on this tandem con-

\section{Introduction}

Thin-film silicon solar cell technology is recognized to have a tremendous potential for low-cost mass production of

G. Bugnon, Dr. G. Parascandolo, Dr. P. Cuony, Dr. M. Despeisse, S. Hänni, Dr. F. Meillaud,

Prof. C. Ballif

Ecole Polytechnique Fédérale de Lausanne (EPFL)

Institute of Microengineering (IMT)

Photovoltaics and Thin-Film Electronics Laboratory

2000 Neuchâtel, Switzerland

E-mail: gregory.bugnon@epfl.ch

Dr. T. Söderström

3S Swiss Solar Systems AG, Schachenweg 24, 3250 Lyss, Switzerland Dr. J. Holovský

Institute of Physics of the ASCR v. v. i.,

Cukrovarnická 10, 16253 Prague, Czech Republic

DOI: 10.1002/adfm.201200299 figuration, record-low production costs of 0.5 dollar per wattpeak were recently announced to be possible even at modest production volumes of around $150 \mathrm{MW} \cdot{ }^{[12]}$

Improving light management is one of the key steps to increase the efficiency of thin-film silicon solar cell devices, which requires minimum parasitic absorption and optimized light scattering by the substrate texture to allow for maximum light trapping in the thin absorber layers. ${ }^{[13-17]}$ However one of the limitations of conventional thin-film silicon solar cell design comes from the inherent low resilience of $\mu \mathrm{c}-\mathrm{Si}: \mathrm{H}$ deposited on substrates with sharp textures. Indeed, during the growth, shadowing effects can lead to the creation of low-quality porous regions resulting in undesired localized current drains in the device. This degrades the overall performance and reliability of the cells, ${ }^{[18-23]}$ and hence discards potentially better morphologies at the expense of light trapping.

Here, we address the specific issue of obtaining high-quality and resilient $\mu \mathrm{c}-\mathrm{Si}: \mathrm{H}$ through plasma-enhanced chemical vapor deposition (PECVD) on challenging morphologies at high 
deposition rates. The role of the plasma conditions on the formation of the localized nanoporous phase is first presented, and the interplay of the substrate morphology is then discussed. Additional experiments regarding material stability versus humidity exposure also provide insights into the importance of both deposition rate and substrate morphology for obtaining dense $\mu \mathrm{c}$ $\mathrm{Si}: \mathrm{H}$ material. This brings a key new understanding of the role of the plasma conditions in influencing the growth of two distinct $\mu \mathrm{c}-\mathrm{Si}: \mathrm{H}$ material phases, both of which can drive solar cell performance. In more general terms, any functional electronic device using $\mu \mathrm{c}$-Si:H material or layers deposited using similar deposition techniques could be affected by the phenomenon.

\section{Results and Discussion}

\subsection{Role of Plasma Process Conditions on the Material Porosity}

Optimized cell-design techniques were recently introduced to increase the resilience of thin- film silicon solar cells to substrate morphology; through the use of doped silicon-rich silicon oxide $\left(\mathrm{SiO}_{\mathrm{x}}\right)$ layers, high performance was retained even on rough substrates. ${ }^{[24-26]}$ Here we evidence the role of plasma conditions on the formation of two distinct $\mu \mathrm{c}-\mathrm{Si}: \mathrm{H}$ material phases and more particularly on the porous regions at high deposition rate. We also show that the use of $\mathrm{SiO}_{\mathrm{x}}$ doped layers can buffer the detrimental effect of this material phase and restore device electrical performance.

Single-junction $\mu \mathrm{c}-\mathrm{Si}: \mathrm{H}$ solar cells were deposited by PECVD on top of zinc oxide ( $\mathrm{ZnO}$ ) electrodes grown by low-pressure chemical vapor deposition (LPCVD). Under our specific LPCVD conditions, as-grown $\mathrm{ZnO}$ naturally develops randomly distributed pyramidal-shaped structures, allowing for strong light scattering and efficient light trapping in the silicon absorber layers. ${ }^{[16]}$ However, as discussed previously, V-shaped valleys with narrow opening angles can become a critical obstacle with current silicon-deposition technologies, as porous defective material easily forms above these regions. For this reason we have developed a smoothening procedure of our as-grown LPCVD ZnO through the use of a plasma treatment. ${ }^{[27]}$ This is done to ease the growth of the $\mu \mathrm{c}-\mathrm{Si}: \mathrm{H}$ by going from $\mathrm{V}$-shaped to U-shaped structures with lower average $\mathrm{ZnO}$ facet inclination. This leads to improved cell electrical parameters such as open-circuit voltage $\left(V_{\mathrm{OC}}\right)$ and fill factor $(F F)$ at the expense of reduced light trapping and current density. In this study the root mean square roughness of the $4.5-\mu$ m-thick front LPCVD $\mathrm{ZnO}$ (Z5) decreases with increasing plasma treatment time, going from $170 \mathrm{~nm}$ (Z5 20') to $120 \mathrm{~nm} \mathrm{(Z5} \mathrm{40')} \mathrm{to} 100 \mathrm{~nm}$ (Z5 60'). This plasma treatment thus provides us with varying substrate morphologies, and allows us to study more systematically the development of porous material and the specific role of the $\mathrm{SiO}_{\mathrm{x}}$ doped layers. Intrinsic $\mu \mathrm{c}$-Si:H layers $1.8 \mu \mathrm{m}$ in thickness were deposited at a constant high rate of $10 \AA \mathrm{s}^{-1}$. The hydrogen input flow rate, $\left[\mathrm{H}_{2}\right]$, was varied and the feed-in power density was adjusted accordingly to get similar Raman crystalline fractions across the series. All other parameters were held constant. Figure 1 shows the resulting conversion efficiencies of solar cells with standard $\mu \mathrm{c}-\mathrm{Si}: \mathrm{H}$ or $\mathrm{SiO}_{\mathrm{x}}$ p-type and

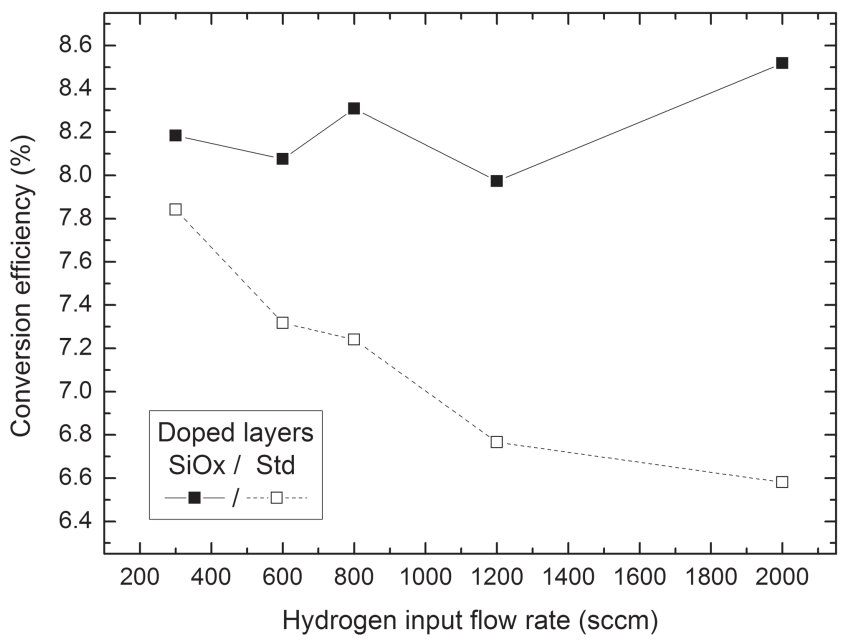

Figure 1. Conversion efficiency of solar cells deposited on Z5 60' with standard $\mu \mathrm{c}-\mathrm{Si}: \mathrm{H}$ (empty symbols) and $\mathrm{SiO}_{\mathrm{x}}$ (filled symbols) doped layers for increasing $\left[\mathrm{H}_{2}\right]$ conditions during intrinsic layer deposition.

n-type doped layers on the smoothest substrate of the study, the Z5 60'. A clear trend can be observed for the solar cells prepared with $\mu \mathrm{c}$-Si:H doped layers, with an efficiency drop from 7.8 to $6.6 \%$ as $\left[\mathrm{H}_{2}\right]$ is increased due to a steady drop of $V_{\mathrm{OC}}$ from $0.48 \mathrm{~V}$ to $0.44 \mathrm{~V}$ and $F F$ from 66.3 to $61.5 \%$. ${ }^{[28]}$ The efficiency remains above $8.0 \%$ when $\mathrm{SiO}_{\mathrm{x}}$ doped layers are used, with $V_{\mathrm{OC}}$ and $F F$ up to $0.51 \mathrm{~V}$ and $70.2 \%$, respectively. A striking difference appears when using $\mathrm{SiO}_{\mathrm{x}}$ doped layers, as the device electrical performance is independent of $\left[\mathrm{H}_{2}\right]$ during intrinsic layer deposition.

To clarify the origin of the efficiency trend observed with $\mu \mathrm{c}-\mathrm{Si}: \mathrm{H}$ doped layers and the effect of $\mathrm{SiO}_{\mathrm{x}}$ layers, advanced material characterization was carried out. X-ray diffraction analysis of the deposited $\mu \mathrm{c}-\mathrm{Si}: \mathrm{H}$ layers on glass is presented in Figure 2. We observe a preferential (220) orientation for all films but there is no trend with respect to $\left[\mathrm{H}_{2}\right]$. Intrinsic stress

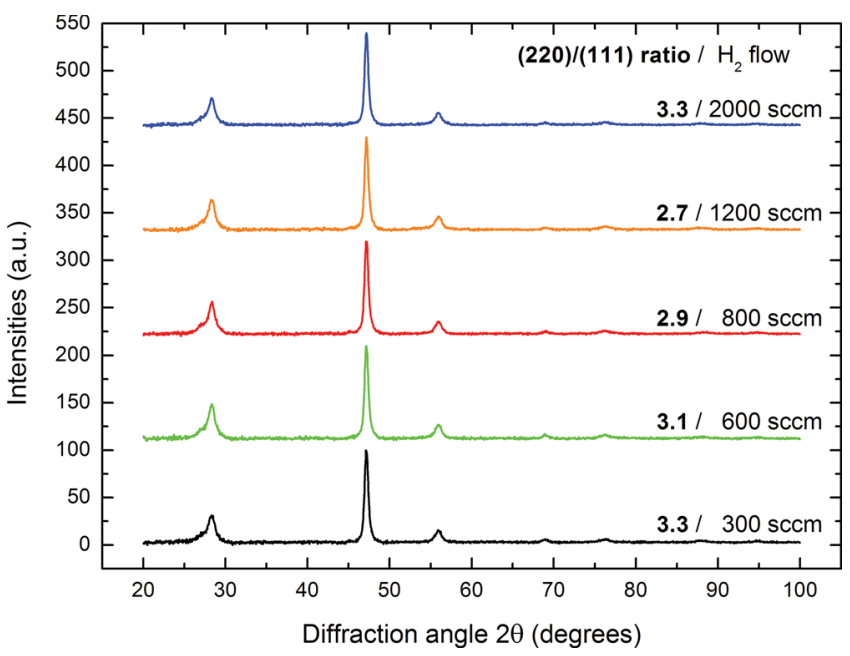

Figure 2. X-ray diffraction patterns of $\mu \mathrm{c}$-Si:H deposited on glass with increasing $\left[\mathrm{H}_{2}\right]$ conditions. The ratio of $(220)$ to $(111)$ peak heights is indicated for each deposition condition. 


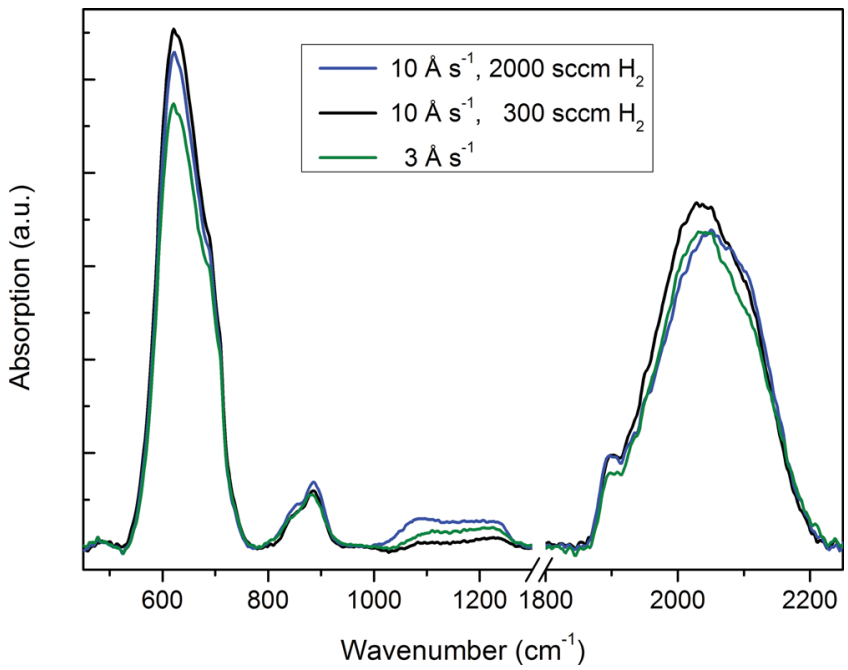

Figure 3. FTIR absorption spectra of $\mu \mathrm{c}-\mathrm{Si}: \mathrm{H}$ deposited on polished c-Si substrates at $10 \AA \mathrm{s} \mathrm{s}^{-1}$ with $2000 \mathrm{sccm} \mathrm{H}_{2}$ (blue line) and $300 \mathrm{sccm} \mathrm{H}_{2}$ (black line) and at a low rate of $3 \AA \mathrm{s}^{-1}$ (green line).

measurements were also performed via the wafer-bending method on wafer strips for all layers deposited with varied $\left[\mathrm{H}_{2}\right]$ but no trend was observed either, as all samples exhibited similar compressive stress values of around -110 $\mathrm{MPa} .{ }^{[29]}$ Fourier-transform infrared (FTIR) vibrational spectra were compared for layers deposited on polished wafers using both the highest and lowest $\left[\mathrm{H}_{2}\right]$ conditions for high deposition rate and compared to the high-quality $\mu \mathrm{c}-\mathrm{Si}: \mathrm{H}$ material deposited at a lower rate of $3 \AA \mathrm{s}^{-1}$. Relevant parts of the spectra are shown in Figure 3. In particular we did not detect the presence of narrow, high stretching modes, which are a signature of poorly passivated grain boundaries susceptible to post-deposition oxidation, ${ }^{[30,31]}$ even for the material with the worst performance in the series. All three materials had very similar structural features and a hydrogen content of around $5 \%$. As a result the method could not discriminate between layers of high and low material quality.

The mid-gap density of states was quantified through Fourier-transform photocurrent spectroscopy (FTPS) performed directly on the cells. ${ }^{[32]}$ FTPS sub-bandgap absorption curves for three solar cells with standard doped layers are plotted in Figure 4 . The same absorption coefficient at $0.8 \mathrm{eV}$ is observed for all $\left[\mathrm{H}_{2}\right]$ conditions, indicating that all intrinsic layers have the same bulk defect density. Similar defect densities were measured on devices with $\mathrm{SiO}_{\mathrm{x}}$ doped layers as well. All the characterization tools used here probe bulk material properties and show that $\left[\mathrm{H}_{2}\right]$ has no significant influence on the bulk quality of the deposited $\mu \mathrm{c}-\mathrm{Si}: \mathrm{H}$ material, despite the observed cell efficiency trend.

Scanning electron microscopy (SEM) cross section images of solar cells were taken for both the highest and lowest $\left[\mathrm{H}_{2}\right]$ conditions input $\mathrm{H}_{2}$ flows with standard and $\mathrm{SiO}_{\mathrm{x}}$ layers. SEM images in Figure 5 show that deposition with high $\left[\mathrm{H}_{2}\right]$ gives rise to nanoporous regions (visible as black lines) which are not observed in the dense material obtained with low $\left[\mathrm{H}_{2}\right]$. The performance variation versus $\left[\mathrm{H}_{2}\right]$ is most likely ascribed to the formation of this nanoporous material phase, which develops

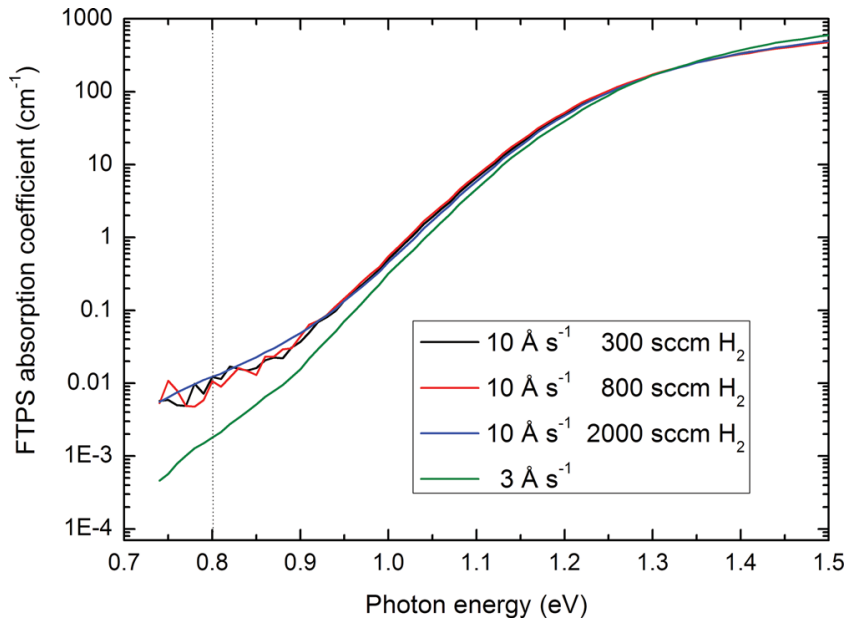

Figure 4. Sub-bandgap absorption coefficient obtained by FTPS on $\mu \mathrm{c}$ $\mathrm{Si}: \mathrm{H}$ p-i-n solar cells with their intrinsic layers deposited at $10 \AA \mathrm{s}^{-1}$ with $300 \mathrm{sccm} \mathrm{H} \mathrm{H}_{2}$ (black line), $800 \mathrm{sccm} \mathrm{H}_{2}$ (red line), and $2000 \mathrm{sccm} \mathrm{H}_{2}$ (blue line) as well as at a low rate of $3 \AA^{-1}$ (green line) on Z5 60' substrates.

from the bottom of the V-shaped valleys where the silicon growth fronts encounter each other during film deposition, and can locally increases the recombination current. Even though the plasma deposition conditions described earlier may provide very similar bulk material properties, the best conditions
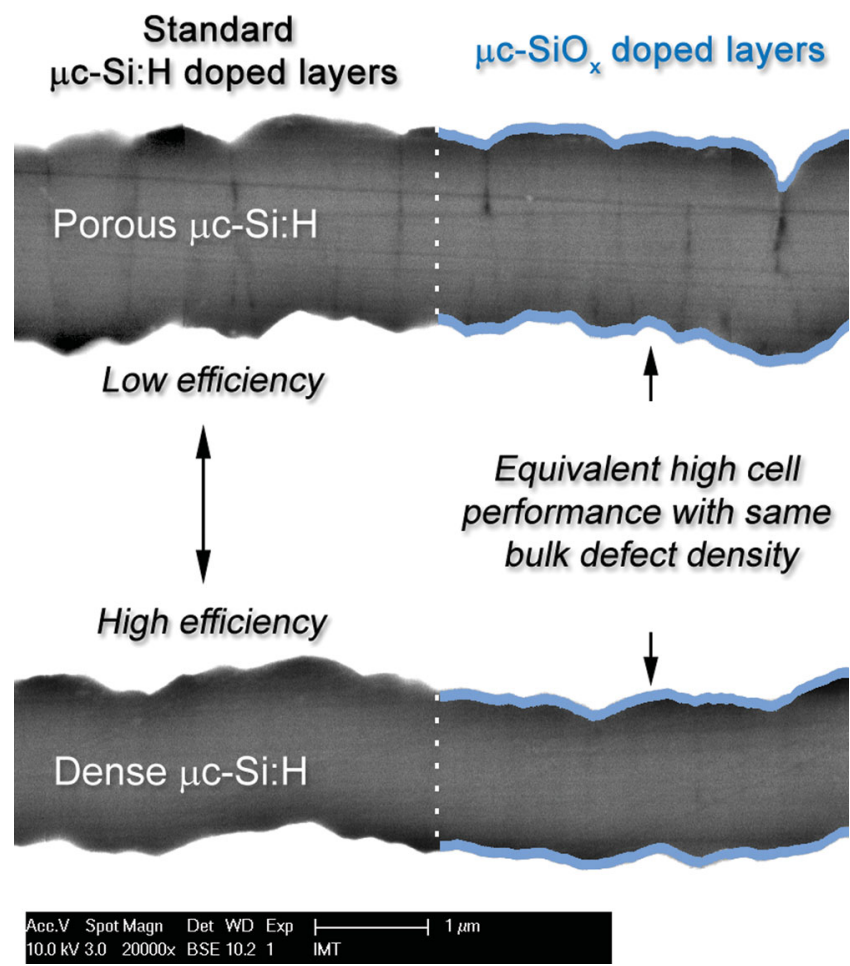

Figure 5. SEM images of $\mu \mathrm{c}-\mathrm{Si}: \mathrm{H}$ p-i-n solar cells with their intrinsiclayers deposited at $10 \AA \mathrm{s}^{-1}$ using a high hydrogen flow rate of $2000 \mathrm{sccm}$ (top) and a low hydrogen flow rate of $300 \mathrm{sccm}$ (bottom) with $\mathrm{SiO}_{x}$ doped layers on the smoothest substrate $Z 560^{\prime}$. Performance recovery in cells with porous intrinsic layers, made using high $\left[\mathrm{H}_{2}\right]$ conditions, is obtained through the use of doped $\mathrm{SiO}_{x}$ layers in place of doped $\mu \mathrm{c}-\mathrm{Si}: \mathrm{H}$ ones. 
with low $\left[\mathrm{H}_{2}\right]$ hinder the development of nanoporous zones and result in the deposition of a denser $\mu \mathrm{c}-\mathrm{Si}: \mathrm{H}$ material. The contribution of these defects to the bulk material properties (i.e., the FTPS absorption value at $0.8 \mathrm{eV}$ ) was shown not to be significant, and they can be considered as two-dimensional surfaces within the device. These results demonstrate that cell performance with regular $\mu \mathrm{c}-\mathrm{Si}: \mathrm{H}$ doped layers is strongly dominated by this nanoporous $\mu \mathrm{c}-\mathrm{Si}: \mathrm{H}$ phase in the intrinsic layer, which is shown to be much more sensitive to the plasma deposition conditions than the bulk $\mu \mathrm{c}-\mathrm{Si}: \mathrm{H}$ material quality itself.

\subsection{Interplay Between Substrate Roughness and the PECVD Process}

In this section we discuss the impact of substrate roughness and morphology on the formation of the nanoporous material phase. The previous device on Z5 60' was co-deposited on two rougher substrates, Z5 40' and Z5 20'. Figure 6a summarizes the cell conversion efficiencies obtained on all substrates for both types of doped layers. Significant gains are again observed when using $\mathrm{SiO}_{\mathrm{x}}$ doped layers thanks to increased $V_{\mathrm{OC}} \times F F$ product. With these $\mathrm{SiO}_{\mathrm{x}}$ layers the losses are small, indicating that the detrimental nanoporous-phase contribution is buffered, and supporting a mechanism in which local current drains (shunts) are quenched. ${ }^{[2]}$

The relative performance increase when going from the standard to the $\mathrm{SiO}_{\mathrm{x}}$ doped layers on all three substrates of this series is presented in Figure 6b. The trend with respect to $\left[\mathrm{H}_{2}\right]$ conditions for the two rougher substrates is similar, but stronger, than that observed for the smoothest substrate Z5 60'. Cell performance is again becoming less sensitive to the intrinsic layer plasma deposition conditions. For low $\left[\mathrm{H}_{2}\right]$ deposition conditions, relative efficiency gains of 4 to $23 \%$ are observed, while for the highest flows they range from 29 to $34 \%$. In the case of the roughest front $\mathrm{ZnO}$ electrode, the relative increase is more constant over the whole range

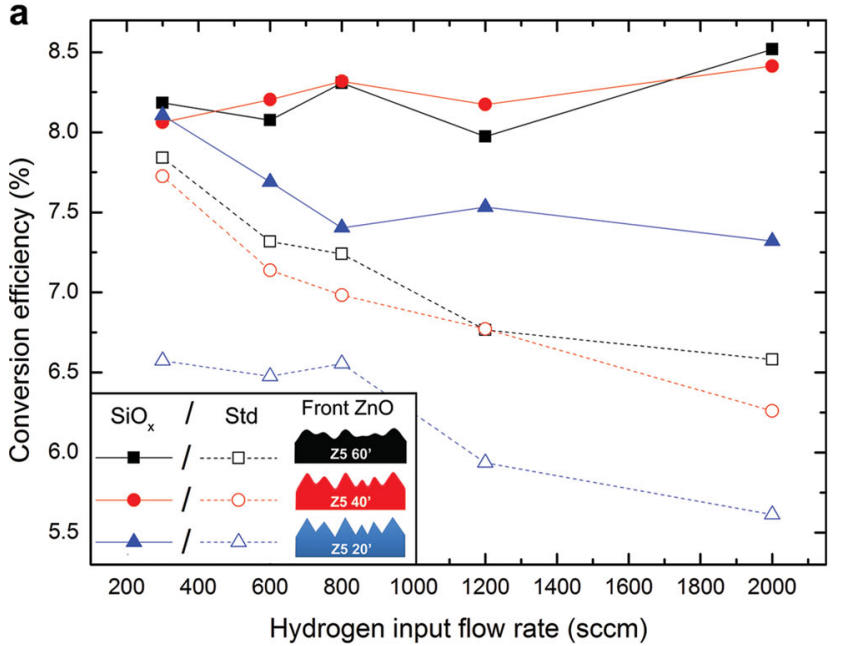

of deposition conditions for the intrinsic layer: as the nanoporous phase is promoted by sharp front-electrode features, the performance recovery thanks to the $\mathrm{SiO}_{\mathrm{x}}$ doped layers is emphasized.

These observations show that the extent of this porous material is affected by the roughness and sharpness of the underlying substrate on which the film grows. The discriminant role of the textured substrate is essential to properly evaluate $\mu \mathrm{c}$ $\mathrm{Si}: \mathrm{H}$ deposition regimes. It is suspected that cells deposited on a substrate even smoother than the Z5 60' studied here, such as flat or optimized sputter-etched $\mathrm{ZnO}$, should not be affected by $\left[\mathrm{H}_{2}\right]$ conditions as the secondary phase will not be promoted by the morphology. As a result, cell performance should be limited and driven only by the bulk material quality: under these conditions clear trends of cell performance with regard to bulk defect density were observed. ${ }^{[33]}$

\subsection{Material Stability and Evidence for the Nanoporous Phase}

Microcrystalline silicon films are known to be more sensitive to oxidation and in-diffusion of atmospheric gases than their amorphous counterparts. ${ }^{[34,20]}$ The performance stability of films embedded in solar cell devices that have been stored simply in air has been studied as well, ${ }^{[20,23,35,36]}$ and is referred to hereafter as dark degradation.

All the previous cells were remeasured after 11 months of being stored in the dark in the air without being encapsulated. No loss of current was observed in any of the cells, as all of the $J_{\text {SC }}$ variations were within $2.5 \%$. The most striking differences appear in the $V_{\mathrm{OC}}$, as it strongly decreases with dark degradation for standard doped layers. The average relative $V_{\mathrm{OC}}$ reduction goes from $4.5 \%$ on Z5 60 ' to $5.5 \%$ on Z5 40 ' to $15.9 \%$ on Z5 $20^{\prime}$. A maximum loss of $27.4 \%$ is observed for the material deposited using high $\left[\mathrm{H}_{2}\right]$ conditions on $\mathrm{Z} 520^{\prime}$, i.e., in the conditions resulting in the highest density of nanoporous phase material. Using $\mathrm{SiO}_{\mathrm{x}}$ layers the $V_{\mathrm{OC}}$ is stable for all the cells,

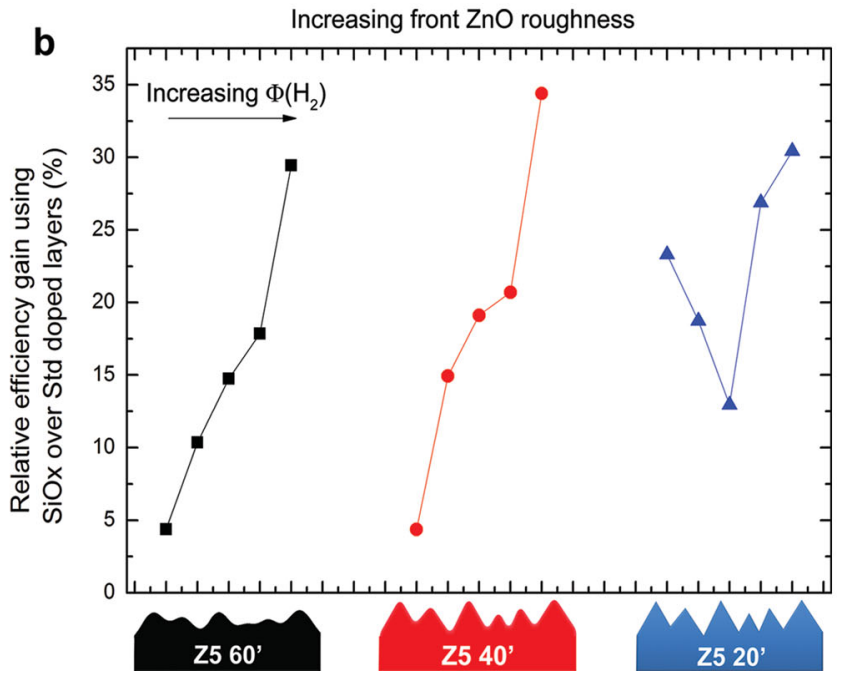

Figure 6. a) Conversion efficiencies of solar cells with standard (empty symbols) and $\mathrm{SiO}_{\mathrm{x}}$ (filled symbols) doped layers on front $\mathrm{ZnO}$ electrodes of increasing roughness through reduced plasma treatment time: $60 \mathrm{~min}$ (black), $40 \mathrm{~min}$ (red), and $20 \mathrm{~min}$ (blue). b) The relative increase in conversion efficiency of $\mu \mathrm{c}-\mathrm{Si}: \mathrm{H}$ solar cells is evaluated when standard doped layers are substituted with $\mathrm{SiO}_{\mathrm{x}}$ layers for the three different front $\mathrm{ZnO}$. 


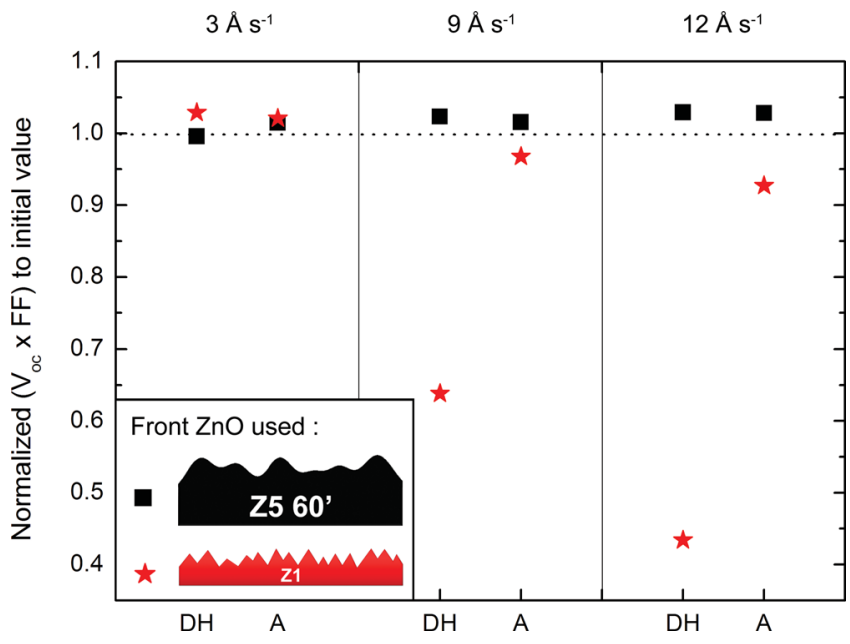

Figure 7. $V_{O C} \times F F$ product of single-junction p-i-n $\mu c-S i: H$ solar cells normalized to initial values after the damp-heat experiment (DH) and annealing step (A) for three growth rates. Cells were co-deposited on two different front ZnO morphologies: a smoothened substrate, Z5 60' (black squares), and a substrate with a high density of sharp pyramidal features, Z1 (red stars). Plotted values are an average over 10 to 16 cells.

degrading $2.8 \%$ at most. It could be that the mixed-phase nature of $\mathrm{SiO}_{\mathrm{x}}$ helps the doped layers act as a barrier to in-diffusion of atmospheric contaminants compared to plain $\mu \mathrm{c}-\mathrm{Si}: \mathrm{H}$, as a-Si:H buffer layer at $\mathrm{p} / \mathrm{i}$ interface of a $\mathrm{n}$-i-p device was proven to be effective with this regard. ${ }^{[37]}$

We present in this section as well an additional set of experiments demonstrating the presence of porous material in the solar cells. As-deposited non-encapsulated $\mu \mathrm{c}$-Si:H cells, using $\mathrm{SiO}_{\mathrm{x}}$ doped layers, were subject to a (non-standard) damp-heat cycle $\left(100 \%\right.$ humidity, $\left.50{ }^{\circ} \mathrm{C}\right)$ during five days to simulate accelerated dark degradation. The cells were then annealed at $180{ }^{\circ} \mathrm{C}$ to induce water vapor desorption, which restored performances to close to their initial values. Relative variations of both $V_{\mathrm{OC}}$ and FF are an indication of $\mu \mathrm{c}-\mathrm{Si}: \mathrm{H}$ susceptibility to water vapor incorporation, as it is favored through the nanoporous zones, while the $J_{\mathrm{SC}}$ is mostly unaffected from the damp-heat/annealing cycle. Figure 7 shows the average value of the $V_{\mathrm{OC}} \times F F$ product over 10 to 16 cells deposited with increasing growth rates of 3 , 9 and $12 \AA \mathrm{s}^{-1}$ on top of two different substrates: a Z5 60' and a thinner $(1 \mu \mathrm{m})$ untreated $\mathrm{ZnO}(\mathrm{Z} 1)$ with more dopant. Major morphological differences between these two substrates are the size of the pyramids of $700 \mathrm{~nm}$ and $180 \mathrm{~nm}$ and with average facet inclinations of $18^{\circ}$ and $30^{\circ}$, respectively (see inset in Figure 7). Z1 exhibits a higher density of shaper valleys, hence promoting the presence of porous material.

While good stability with regard to damp-heat tests is observed for the cells deposited on the smoothest substrate, Z5 60', major differences appear on Z1. At a low growth rate of $3 \AA \mathrm{s}^{-1}$ damp-heat experiments do not lead to a decrease of the electrical performance of cells grown on any substrate. Above this growth rate, cell performance on $\mathrm{Z} 1$ is strongly affected by the damp-heat test, with a $V_{\mathrm{OC}} \times F F$ reduction of $35 \%$ at $9 \AA \mathrm{s}^{-1}$ and above $55 \%$ at $12 \AA \mathrm{s}^{-1}$. We observe as well that annealing recovers almost all of the losses induced by the damp-heat test. In contrast, Z5 60' allows for the growth of highly stable material with regard to the damp-heat experiment, thanks to a much smoother morphology that reduces nanoporous phase formation. Contribution to $\mathrm{FF}$ variations due to the $\mathrm{ZnO}$ instability itself still exists. However, comparing different devices with the same front and back $\mathrm{ZnO}$ gives a direct comparison of the actual impact of $\mu \mathrm{c}-\mathrm{Si}$ intrinsic layer instability. It is worth mentioning here that the $\mathrm{Z} 1$ being more doped than the Z5, it is also less sensitive to degradation with respect to humidity exposure. ${ }^{[38]}$

This original method for simulating accelerated dark degradation demonstrates the importance of both deposition rate and surface morphology on the formation of the $\mu \mathrm{c}-\mathrm{Si}: \mathrm{H} \mathrm{sec}$ ondary, porous phase. Increased porosity is observed at high growth rates and clearly relates to the substrate sharpness and the density of potential sites of void formation.

\subsection{Perspectives and Record Single-Junction $\mu \mathrm{c}$-Si:H Cell Performance}

From this study we conclude that $\mathrm{SiO}_{\mathrm{x}}$ doped layers reduce the negative impact of nanoporous regions on cell electrical performance. Their use allows the electrical performance of solar cells with porous intrinsic layers to match that of cells with denser intrinsic material with similar bulk defect densities. This is further supported by the observation of almost constant solar cell efficiencies on Z5 60' and Z5 40' in Section 2.2 , independent of the hydrogen dilution used, which is consistent with the identical bulk properties exhibited by the different intrinsic layers. We demonstrated that the electrical gain obtained when using $\mathrm{SiO}_{\mathrm{x}}$ doped layers relates, at least partly, to the presence of the nanoporous phase, due to either the deposition conditions or the substrate morphology. This performance enhancement may come from a shunt-quenching effect as already proposed. ${ }^{[24]}$ Another possibility is that there is a reduction of boron cross-contamination from the underlying p-layer. This hypothesis would be corroborated by electric-field profile measurements in $\mu \mathrm{c}-\mathrm{Si}: \mathrm{H}$ p-i-n solar cells done by crosssectional scanning Kelvin probe microscopy, in which negative charges at the cluster boundaries are speculated to be related to the presence of activated boron. ${ }^{[39]}$ We could show here as well that the use of $\mathrm{SiO}_{\mathrm{x}}$ doped layers alone is not sufficient to negate completely this porous defective material phase influence. In order to reach high efficiency thin-film silicon solar cells, further optimized substrate morphologies, $\mathrm{SiO}_{\mathrm{x}}$ layers and intrinsic $\mu \mathrm{c}-\mathrm{Si}: \mathrm{H}$ deposition processes, especially at high growth rates, altogether are thus required.

Regarding the formation of the porous phase, a clear identification of the critical plasma parameters affecting its appearance is mandatory to gain further insights into plasma-surface interactions (control of incident radical flux, ion bombardment energy, densification processes, shadowing and re-emission processes for coverage considerations, etc.), as bulk material quality alone was proven not to be sufficient for reaching highefficiency solar cells.

With our new findings we further optimized single-junction $\mu \mathrm{c}-\mathrm{Si}: \mathrm{H}$ solar cells on LPCVD ZnO. Using the intrinsic $\mu \mathrm{c}$-Si:H material deposited at $3 \AA \mathrm{s}^{-1}$ presented in Section 2.1, and through careful optimization of the $\mathrm{SiO}_{\mathrm{x}}$ doped layers and 

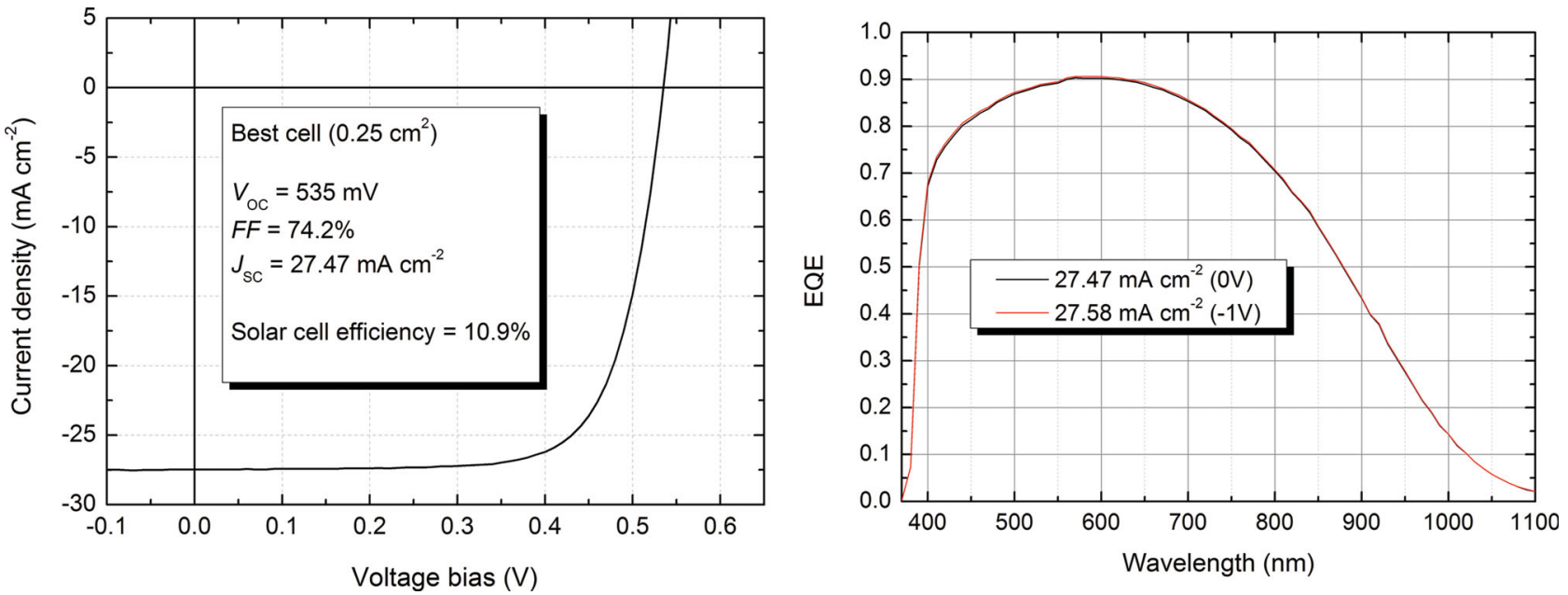

Figure 8. $I-V$ and external quantum efficiency (EQE) under $0 \mathrm{~V}$ and $-1 \mathrm{~V}$ of the best-performing single-junction p-i-n $\mu \mathrm{c}$-Si: $\mathrm{H}$ solar cell $\left(0.25 \mathrm{~cm}^{2}\right)$ with an intrinsic layer thickness of $2 \mu \mathrm{m}$ deposited at $3 \AA \mathrm{s}^{-1}$ with optimized $\mathrm{SiO}_{\mathrm{x}}$ doped layers and interfaces along with an antireflective coating at the air/glass interface.

control of interfaces, a cell efficiency of $10.9 \%$ was achieved, the highest reported in the literature according to our knowledge. Figure 8 shows both the current-voltage $(I-V)$ curve and EQE measurements of this cell with a $2-\mu \mathrm{m}$-thick intrinsic layer. The $V_{\mathrm{OC}}$ is $535 \mathrm{mV}$, the $F F$ is $74.2 \%$ and the $J_{\mathrm{SC}}$ increases from $26.5 \mathrm{~mA} \mathrm{~cm}^{-2}$ to $27.5 \mathrm{~mA} \mathrm{~cm}^{-2}$ with the use of a new antireflective coating developed in our laboratory. ${ }^{[40]}$ The very small difference between EQE measurements under no bias and with a reverse voltage of $-1 \mathrm{~V}$ demonstrates low recombination and good collection of photogenerated carriers in the intrinsic layer. The $\mu \mathrm{c}$-Si:H exhibits very good bulk material quality as demonstrated by the low FTPS absorption coefficient at $0.8 \mathrm{eV}$, which is below $2 \times 10^{-3} \mathrm{~cm}^{-1}$, as shown in Figure 4. Its highly dense structure was confirmed by its high stability during damp-heat tests done on rough substrates for both single-junction and micromorph configurations.

\section{Conclusion}

This study highlights a fundamental aspect of $\mu \mathrm{c}$-Si:H deposition on highly textured substrates: the contribution of two different phases of $\mu \mathrm{c}-\mathrm{Si}: \mathrm{H}$ material to overall solar cell efficiency, both of which can drive cell performance. Defective localized nanoporous regions were found to be significantly more sensitive to plasma process conditions and to substrate morphology than the bulk phase. Although FTPS and FTIR are the preferred optoelectrical characterization tools to determine $\mu \mathrm{c}$-Si:H quality and identify optimum intrinsic layer process conditions, we clearly demonstrated that they are not sufficient to fully relate device performance to material quality. This becomes especially relevant when depositing on substrates with sharp features, which are essential for achieving optimum light trapping and optical performance. On such substrates, and depending on plasma conditions, it is a challenge to deposit dense material at a high deposition rate, which is a prerequisite for achieving high electrical performance and, ultimately, high conversion efficiency.

\section{Experimental Section}

Photovoltaic Device Preparation and Measurement: Single-junction $\mu \mathrm{c}-\mathrm{Si}: \mathrm{H} \mathrm{p}$-i-n solar cells were prepared with silicon layers deposited in a medium-sized version (50 $\times 60 \mathrm{~cm}^{2}$ powered electrode area) of an industrial PECVD KAI reactor with a deposition temperature of $180^{\circ} \mathrm{C}$. Silane and hydrogen were used for the deposition of intrinsic layers. To keep a constant Raman crystallinity for the high deposition rate series at $10 \AA \mathrm{s}^{-1}$, only a reduction of $20 \%$ in power density was required when reducing $\left[\mathrm{H}_{2}\right]$ from 2000 to 300 standard cubic centimeters per minute $(\mathrm{sccm})$, to compensate for increased residence time, thanks to a quite high level of silane depletion. ${ }^{[41]}$ With reduced $\left[\mathrm{H}_{2}\right]$, silane dissociation efficiency increases from $80 \%$ to $85 \%$ and powder formation is also favored. ${ }^{[42]}$ Trimethylboron and phosphine gases were used for p-type and n-type doping, respectively, and $\mathrm{SiO}_{\mathrm{x}}$ doped layers were obtained adding $\mathrm{CO}_{2}$ to the deposition gas mixtures. The front contact consisted of textured zinc oxide $(\mathrm{ZnO})$ grown by low-pressure chemical vapor deposition (LPCVD) on standard AF45 Schott glass substrates, and were subsequently smoothened through the use of an argon-based plasma treatment. The cells were patterned to $0.25 \mathrm{~cm}^{2}$, and the back contact was LPCVD ZnO covered with a white dielectric reflector. Opencircuit voltage $\left(V_{O C}\right)$ and fill factor $(F F)$ were derived from the $I-V$ measurements of the cells, measured with a dual lamp Wacom solar simulator (WXS-220S-L2) in standard test conditions $\left(25^{\circ} \mathrm{C}, \mathrm{AM} 1.5\right.$ global reference spectrum, $100 \mathrm{~mW} \mathrm{~cm}{ }^{-2}$ ). The short-circuit current densities $\left(U_{s c}\right)$ reported here, and used to calculate the efficiencies, were always determined by integrating the product of the external quantum efficiency and the incoming photon flux of the AM1.5 global reference spectrum.

Material Characterization: Fourier transform infrared (FTIR) spectroscopy was carried out with a Nicolet 8700 instrument on $\mu \mathrm{C}$ $\mathrm{Si}: \mathrm{H}$ layers deposited on $\mathrm{c}-\mathrm{Si}$ wafers to provide chemical bonding information. Preferential crystal orientation of the $\mu \mathrm{c}-\mathrm{Si}: \mathrm{H}$ material was investigated with X-ray diffraction analysis of layers deposited on flat AF45 glass. Intrinsic stress measurements were done using the wafer-bending method on polished wafer strips of $50 \times 10 \times 0.3 \mathrm{~mm}^{3}$ using an Ambios XP2 profilometer. Fourier transform photocurrent spectroscopy (FTPS) was done with a Nicolet 8700 directly on $\mathrm{p}-\mathrm{i}-\mathrm{n}$ cell devices to evaluate the bulk defect density of the intrinsic $\mu \mathrm{c}-\mathrm{Si}: \mathrm{H}$. A Philips XL-30 field emission gun scanning electron environmental microscope (FEG-ESEM) with an acceleration voltage ranging between 5 to $30 \mathrm{kV}$ was used to evaluate qualitatively the formation of nanoporous regions in the material. 


\section{Acknowledgements}

The authors would like to thank Aafke Bronneberg for FTIR analysis and expertise on IR spectra interpretation. Zachary Holman and Lara Sands are thanked for carefully reviewing the manuscript. This work was supported by the Swiss Federal Energy Office "OFEN" under Project. No. 101191 and by the EU FP7 PEPPER project.

Received: January 31, 2012 Revised: April 13, 2012

Published online:

[1] International Energy Agency (IEA), Technology Roadmap - Solar Photovoltaic Energy, 2010, http:||www.iea.org|papers|2010| pv_roadmap.pdf (accessed May 2012).

[2] M. Z. Jacobson, M. A. Delucchi, Energy Policy 2011, 39, 1154.

[3] A. V. Shah, H. Schade, M. Vanecek, J. Meier, E. Vallat-Sauvain, N. Wyrsch, U. Kroll, C. Droz, J. Bailat, Prog. Photovolt: Res. Appl. 2004, 12, 113.

[4] K. Saito, M. Sano, S. Okabe, S. Sugiyama, K. Ogawa, Sol. Energy Mater. Sol. Cells 2005, 86, 565.

[5] I. A. Yunaz, A. Yamada, M. Konagai, Jpn. J. Appl. Phys. 2007, 46, 1152.

[6] T. Matsui, H. Jia, M. Kondo, Prog. Photovolt: Res. Appl. 2010, 18, 48.

[7] M. Konagai, Jpn. J. Appl. Phys 2011, 50, 030001.

[8] B. Yan, G. Yue, L. Sivec, J. Yang, S. Guha, C.-S. Jiang, Appl. Phys. Lett. 2011, 99, 113512.

[9] J. Meier, P. Torres, R. Platz, S. Dubail, U. Kroll, J. A. A. Selvan, N. Pellaton Vaucher, Ch. Hof, D. Fischer, H. Keppner, A. Shah, K.-D. Ufert, P. Giannoules, J. Koehler, Mater. Res. Soc. Symp. Proc. 1996, 420, 3.

[10] F. Meillaud, A. Shah, C. Droz, E. Vallat-Sauvain, C. Miazza, Sol. Energy Mater. Sol. Cells 2006, 90, 2952.

[11] A. Feltrin, A. Freundlich, Renewable Energy 2008, 33, 180.

[12] OerlikonSolar, PressreleasefromJan. 16, 2012, http://www.oerlikon.com/ solar/en/media/press-releases-detail/9082/(accessed May 2012).

[13] J. Muller, B. Rech, J. Springer, M. Vanecek, Sol. Energy 2004, 77, 917.

[14] M. Boccard, P. Cuony, C. Battaglia, M. Despeisse, C. Ballif, Phys. Status Solidi RRL 2010, 4, 326.

[15] M. Berginski, J. Hupkes, M. Schulte, G. Schope, H. Stiebig, B. Rech, M. Wuttig, J. Appl. Phys. 2007, 101, 074903.

[16] S. Nicolay, S. Faÿ, C. Ballif, Cryst. Growth Des. 2009, 9, 4957.

[17] H. Sai, H. Jia, M. Kondo, J. Appl. Phys. 2010, 108, 044505.

[18] D. Knoesen, R. E. I. Schropp, W. F. Van Der Weg, Mater. Res. Soc. Symp. Proc. 1995, 377, 597.

[19] Y. Nasuno, M. Kondo, A. Matsuda, Jpn. J. Appl. Phys. 2001, 40, 303.

[20] F. Finger, R. Carius, T. Dylla, S. Klein, S. Okur, M. Günes, IEE Proc. Circuits Dev. Syst. 2003, 150, 300.
[21] M. Python, E. Vallat-Sauvain, J. Bailat, D. Dominé, L. Fesquet, A. Shah, C. Ballif, J. Non-Cryst. Solids 2008, 354, 2258.

[22] H. B. T. Li, R. H. Franken, J. K. Rath, R. E. I. Schropp, Sol. Energy Mater. Sol. Cells 2009, 93, 338.

[23] M. Boccard, P. Cuony, M. Despeisse, D. Dominé, A. Feltrin, N. Wyrsch, C. Ballif, Sol. Energy Mater. 2011, 95, 195.

[24] M. Despeisse, G. Bugnon, A. Feltrin, M. Stueckelberger, P. Cuony, F. Meillaud, A. Billet, C. Ballif, Appl. Phys. Lett. 2010, 96, 073507.

[25] P. Cuony, M. Marending, D. T. L. Alexander, M. Boccard, G. Bugnon, M. Despeisse, C. Ballif, Appl. Phys. Lett. 2010, 97, 213502.

[26] P. Cuony, D. T. L. Alexander, I. Perez-Wurfl, M. Despeisse, G. Bugnon, M. Boccard, T. Söderström, A. Hessler-Wyser, C. Hébert, C. Ballif, Adv. Mater. 2012, 24, 1182.

[27] M. Boccard, T. Söderström, P. Cuony, C. Battaglia, S. Hänni, S. Nicolay, L. Ding, M. Benkhaira, G. Bugnon, A. Billet, M. Charrière, F. Meillaud, M. Despeisse, C. Ballif, IEEE J. Photovoltaics 2012, DOI: 10.1109/JPHOTOV.2011.2180514.

[28] G. Bugnon, A. Feltrin, F. Meillaud, J. Bailat, C. Ballif, J. Appl. Phys. 2009, 105, 064507.

[29] G. Bugnon, R. Bartlome, G. Parascandolo, M. Despeisse, J. Holovsky, F. Meillaud, C. Ballif, Proc. 5th World Conf. PVSEC WIP Renewable Energies, Munich 2010, p. 3009-3012.

[30] A. H. M. Smets, T. Matsui, M. Kondo, J. Appl. Phys. 2008, 104, 034508.

[31] A. C. Bronneberg, A. H. M. Smets, M. Creatore, M. C. M. van de Sanden, J. Non-Cryst. Solids 2011, 357, 884.

[32] M. Vanecek, A. Poruba, Appl. Phys. Lett. 2002, 80, 719.

[33] A. Gordijn, L. Hodakova, J. K. Rath, R. E. I. Schropp, J. Non-Cryst. Solids 2006, 352, 1868.

[34] S. Veprek, Z. Iqbal, R. O. Kuhne, P. Capezzuto, F.-A. Sarott, J. K. Gimzewski, J. Phys. C: Solid State Phys. 1983, 16, 62416262.

[35] T. Matsui, M. Kondo, A. Matsuda, Jpn. J. Appl. Phys. 2003, 42, 901.

[36] W. Frammelsberger, P. Lechner, R. Lechner, W. Psyk, R. Geyer, S. Dandl, A. Haslauer, H. Maurus, D. Lundszien, H. Popp, E. Diegel, R. Walter, U. Weber, V. Hagemann, Proc. 5th World Conf. PVSEC WIP Renewable Energies, Munich 2010, p. 2788-2792.

[37] S. Taira, M. Shima, K. Murata, M. Tanaka, Proc. 3rd World Conf. PVSEC WIP Renewable Energies, Munich 2003, p. 1816-1819.

[38] J. Steinhauser, S. Meyer, M. Schwab, S. Faÿ, C. Ballif, U. Kroll, D. Borrello, Thin Solid Films 2011, 90, 558.

[39] D. Dominé, J. Bailat, M. Python, N. Wyrsch, C. Ballif, H. R. Moutinho, C.-S. Jiang, M. M. Al-Jassim, Proc. 22nd EU-PVSEC WIP Renewable Energies, Munich 2007, p. 2203-2207.

[40] J. Escarré, K. Söderström, M. Despeisse, S. Nicolay, C. Battaglia, G. Bugnon, L. Ding, F. Meillaud, F.-J. Haug, C. Ballif, Sol. Energy Mater. Sol. Cells 2012, 98, 185.

[41] B. Strahm, A. A. Howling, L. Sansonnens, C. Hollenstein, Plasma Sources Sci. Technol. 2007, 16, 80.

[42] G. Parascandolo, R. Bartlome, G. Bugnon, T. Söderström, B. Strahm, A. Feltrin, C. Ballif, Appl. Phys. Lett. 2010, 96, 233508 